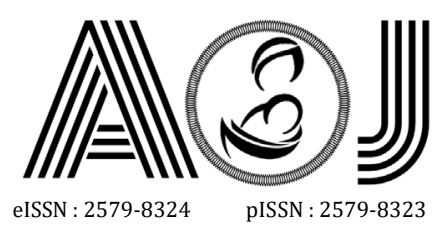

\title{
RESEARCH
}

\section{Description of Anemia Case on Referral Patients At Mother and Child Hospital Siti Hawa Padang in January - December 2018}

\author{
Herti Marni ${ }^{1}$, Desmiwarti ${ }^{2}$
}

Affiliations: 1. Resident of Obstetrics and Gynecology, Faculty of Medicine, Andalas University, Dr. M. Djamil Central General Hospital Padang; 2. Sub Division of Social Obstetrics and Gynecology, Obstetrics and Gynecology Department, Faculty of Medicine, Andalas University, Dr. M. Djamil Central General Hospital Padang

Correspondence: Herti Marni, email: hertimarni01@gmail.com, Hp:081364469077

\begin{abstract}
Anemia is the most common hematological disorder in pregnant women, primarily caused by iron deficiency. Many factors affect hemoglobin levels such as socioeconomic, educational level, age, parity, etc. Globally, there are 40.1\% of women who experience anemia in pregnancy, with more than half due to iron deficiency. This study is a descriptive study using a cross sectional design with a population of anemic obstetric patients who were treated at Siti Hawa Hospital Padang from January 2018 to December 2018. All populations that met the inclusion criteria were taken as samples, so that 50 samples were obtained. Total population of hospitalized obstetric patient was 1994 patient. The results showed that the most obstetric patients with anemia found in 20-35 years old patients, in the second and third pregnancies. Most commonly found in non-bleeding patients with moderate degrees of anemia. The most patients came from Lubuk Begalung, Padang Timur, and Pauh. In addition, 3 patients were referred from outside the city of Padang, which are from the Mentawai Islands, Dharmasraya, and Pariaman.
\end{abstract}

Keywords: hyperthyroid, pregnancy , IUGR

\section{INTRODUCTION}

Anemia in pregnancy is a risk factor for both mother and fetus. Research has found that maternal outcomes, including low birth weight, neonatal and prenatal mortality, premature birth, and fetal death are the effects of anemia during pregnancy.

Anemia in pregnancy can be asymptomatic and can be diagnosed after routine screening. Signs and symptoms are often not specific with fatigue appear as the most common symptoms. Women may also complain of weakness, headaches, palpitations, dizziness, dyspnea, and hair loss. Signs of anemia may occur without low Hb. Anemia divided by its severity into mild, moderate and severe anemia. Management of anemia depends on the cause and severity of the anemia. Consisting of blood transfusion and management of the causes of anemia itself. 


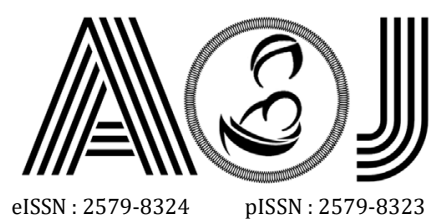

eISSN : 2579-8324
pISSN : 2579-8323

Ruang Redaksi Andalas Obstetrics and Gynecology Journal, Lantai 3 PPDS Obstetri dan Ginekologi Universitas Andalas, RSUP DR. M. Djamil Padang, Jl. Perintis Kemerdekaan Padang, Sumatera Barat 25127

Website:

http://jurnalobgin.fk.unand.ac.id/index.php/JOE

\section{METHOD}

This research is descriptive in order to know the description of referral obstetric patients with anemia at Siti Hawa Hospital, Padang. The study was conducted at RSIA Siti Hawa, Padang from January 2018 to December 2018. The study sample is all populations that meet the inclusion and exclusion criteria. Data regarding the sample was taken from the medical records of patients who were recorded as having anemia who had been treated in the Inpatient Room at Siti Hawa Hospital in Padang in January 2018 until December 2018. The inclusion criteria in this study were patients diagnosed with anemia with $\mathrm{Hb}<10 \mathrm{mg} / \mathrm{dl}$ treated at Siti Hawa Hospital, Padang.

\section{RESULT}

Of the total population of obstetric patients treated at RSIA Siti Hawa during January December 2018 were 1994 patients. While the total sample that met the inclusion criteria were 50 patients.

Table 1. Description on the total population compared to the total sample from the study

\begin{tabular}{lcc}
\hline Total Population & Total Sample & Percentage \\
\hline 1994 patients & 50 patients & $2.5 \%$ \\
\hline
\end{tabular}

Data obtained from the medical records of RSIA Siti Hawa Padang, showed referral obstetric patients who experienced anemia from January 2018 to December 2018 were as many as 50 patients. In this study, patients who were included in the inclusion criteria were mostly at the age of 20-35 years old, followed by $>35$ years old, and $<20$ years old.

Table 2. Description of Anemia in Obstetric Patients Based on Age

\begin{tabular}{lcc}
\hline Age & Total $(\mathbf{n})$ & Percentage \\
\hline$<20$ yrs old & 3 & $6 \%$ \\
$20-35$ yrs old & 36 & $72 \%$ \\
$>35$ yrs old & 11 & $22 \%$ \\
\hline
\end{tabular}

Anemic patients were mostly found in patients with second and third pregnancies at $44 \%$, followed by patients with first pregnancy at $22 \%$.

Table 3. Description of Anemia in Obstetric Patients by Number of Pregnancy

\begin{tabular}{lcc}
\hline Total Pregnancy & Total $(\mathbf{n})$ & Percentage \\
\hline G1 & 17 & $34 \%$ \\
G2-G3 & 22 & $44 \%$ \\
$\geq$ G4 & 11 & $22 \%$ \\
\hline
\end{tabular}




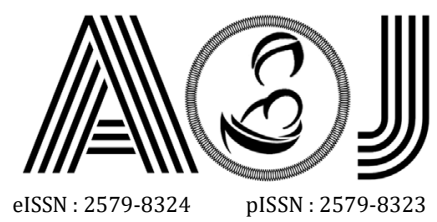

eISSN : 2579-832

Ruang Redaksi Andalas Obstetrics and Gynecology Journal, Lantai 3 PPDS Obstetri dan Ginekologi Universitas Andalas, RSUP DR. M. Djamil Padang, Jl. Perintis Kemerdekaan Padang, Sumatera Barat 25127

Based on data obtained from medical records, the most common cause of anemia due to non-bleeding cases was $80 \%$, and $20 \%$ was due to peripartum hemorrhage.

Table 4. Description of Anemia Cases in Obstetric Patients Based on Diagnosis

\begin{tabular}{lcc}
\hline Diagnose & Total $(\mathbf{n})$ & Percentage \\
\hline Bleeding anemia & 10 & $20 \%$ \\
Non-bleeding anemia & 40 & $80 \%$ \\
\hline
\end{tabular}

Of the 50 patients observed, $92 \%$ had moderate anemia, and the rest had severe anemia.

Table 5. Description of Degrees of Anemia in Obstetric Patients

\begin{tabular}{lcc}
\hline Degree of Anemia & Total $(\mathbf{n})$ & Percentage \\
Moderate anemia $(7.0-9.9 \mathrm{~g} / \mathrm{dl})$ & 46 & $92 \%$ \\
Severe anemia $(<7.0 \mathrm{~g} / \mathrm{dl})$ & 4 & $8 \%$ \\
\hline
\end{tabular}

The most found obstetric patients with anemia came from Lubuk Begalung Sub district, followed by East Padang and Pauh. There were also 3 patients from outside Padang City.

Table 6. Description of Anemia Cases in Obstetric Patients Based on Patient Origin

\begin{tabular}{lcc}
\hline Address & Total $(\mathbf{n})$ & Percentage \\
\hline Bungus Teluk Kabung & 6 & $12 \%$ \\
Koto Tangah & 1 & $2 \%$ \\
Kuranji & 3 & $6 \%$ \\
Lubuk Begalung & 10 & $20 \%$ \\
Lubuk Kilangan & 3 & $6 \%$ \\
Nanggalo & 1 & $2 \%$ \\
Padang Barat & - & - \\
Padang Selatan & 4 & $8 \%$ \\
Padang Timur & 9 & $18 \%$ \\
Padang Utara & 2 & $4 \%$ \\
Pauh & 8 & $16 \%$ \\
Luar Kota Padang & 3 & $6 \%$ \\
\hline
\end{tabular}

\section{DISCUSSION}

\section{Description of Anemia Cases in Obstetric Patients by Age}

A study conducted by WHO in 2011 of 23 million pregnant women worldwide reported 38\% had anemia in pregnancy. Anemia is the most common hematological disorder found in pregnant women. The most common cause is iron deficiency. Many factors affect hemoglobin levels such as socioeconomic, education level, age, parity, etc. 


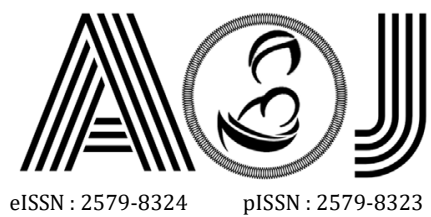

eISSN : 2579-8324
pISSN : 2579-8323

In this study it was found 50 obstetric patients who met the inclusion criteria within 12 months. Mostly they were at the age of 20-35 years, followed by age $>35$ years, and age $<20$ years. These results are in line with the study of Maka (2017) where the most anemic ages were in pregnancy $19-24$ years (47\%), followed by $25-29$ years $(34 \%),<19$ years $(11 \%)$, and $>30$ years $(8 \%)^{12}$.

A similar study conducted by Rajamouli (2016) of 269 women showed $58.36 \%$ had anemia. Mostly they were at the age of $20-24$ years ( $57.4 \%)$, followed by $25-29$ years ( $14.6 \%$ ), and aged $<20$ years by $28 \% 13$. Another study conducted by Suryanarayana (2016) showed the prevalence of anemia in pregnant women as much as $64 \%$. Mostly they were at the age of $21-25$ years $(48.2 \%), 26-35$ years $(26.9 \%), 15-20$ years $(14.5 \%)$, and $>35$ years $(11.3 \%)^{14}$.

\section{Description of Anemia Cases in Obstetric Patients Based on Number of Pregnancy}

In this study, anemia patients were most commonly found in G2 and G3 (44\%). Similar studies conducted by Rajamouli (2016) showed the highest prevalence of anemia in G2 (43.3\%), G1 (38.2\%), and G3 (18.5\%). These results are in accordance with the Suryanarayana (2016) study in which anemia prevalence is mostly prevalent in G2 (48.6\%), followed by G1 (37.5\%), and> G3 (13.9\%). The bivariate test in this study showed that the incidence of anemia was directly proportional to the number of pregnancies ${ }^{13,14}$.

\section{Description of Anemia Cases in Obstetric Patients Based on Diagnosis}

Of the 50 respondents, $20 \%$ had anemia due to bleeding. Some of these are in post partum patients with residual placenta, laceration of the birth canal, placental retention, uterine inertia, and incomplete abortion. The rest are obstetric patients with anemia without bleeding.

A research conducted by Maka (2017) showed that $90 \%$ of anemia in pregnancy is caused by iron deficiency with microscopic hypochromic microscopic features. In this study, anemia was proven to be related to nutrition and socioeconomic conditions ${ }^{12}$. The lower the socioeconomic status, the higher the prevalence of anemia in pregnancy ${ }^{13}$. Anemia is a common disease found in pregnancy, especially in developing countries and is in line with maternal mortality and morbidity ${ }^{12}$.

\section{Description of the Degree of Anemia in Obstetric Patients}

Patients were grouped into 3 groups based on the degree of anemia, namely mild anemia $(\mathrm{Hb}: 10-10.9 \mathrm{~g} / \mathrm{dl})$, moderate anemia $(\mathrm{Hb}: 7.0-9.9 \mathrm{~g} / \mathrm{dl})$, and severe anemia $(\mathrm{Hb}:<7.0 \mathrm{~g} / \mathrm{dl})$ (WHO, 2011). Of the 50 patients examined, 92\% had moderate anemia, and the rest had severe anemia ${ }^{15}$. 


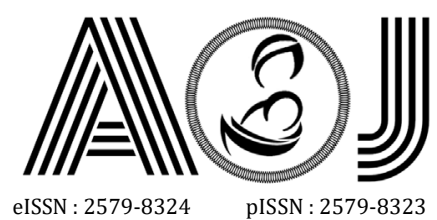

eISSN : 2579-8324
pISSN : 2579-8323

Research by Maka (2017) showed 54\% of anemia patients in pregnancy possessed moderate anemia, $38 \%$ with mild anemia, and $18 \%$ with severe anemia ${ }^{12}$. Whereas Suryanarayana (2016) showed that the average levels of hemoglobin of anemia patients in pregnancy was $10.3 \mathrm{~g} / \mathrm{dl}^{14}$.

\section{Overview of Anemia Cases in Obstetric Patients Based on Patient Origin}

Obstetric patients with anemia recorded from January 2018 to December 2018 at Siti Hawa Hospital, Padang came from 10 villages in Padang City as well as from outside Padang City. Mostly came from Lubuk Begalung Urban Village (20\%), followed by Padang Timur (18\%), and Pauh (16\%). The least came from Koto Tangah and Nanggalo. In addition, 3 patients were referred from outside the city of Padang, namely from Mentawai Islands, Dharmasraya, and Pariaman.

\section{CONCLUSION}

The results show that mostly obstetric patients with anemia are at the age of 20-35 years old and in the second and third pregnancies. Most commonly found in non-bleeding patients with moderate anemia. Most of the patients came from Lubuk Begalung, East Padang and Pauh. In addition, 3 patients are referred from outside the city of Padang, namely from Mentawai Islands, Dharmasraya, and Pariaman.

\section{REFERENCES}

1. Chowdhury S, Rahman M, Moniruddin ABM. Anemia in Pregnancy. Med. Today. 2014; 26(1): 49-52.

2. Kemenkes RI. Riset Kesehatan Dasar. Jakarta: Balitbang; 2013.

3. Clinical Guideline: Anemia in Pregnancy. SA Maternal \& Neonatal Community of Practice. 2019; 1-20.

4. Bivalkar NY, Wingkar KC, Joshi AG, Jagtap S. Assessment of Severity and Types of Anemia During Pregnancy in Rural Population in Western Maharashtra. Indian Journal of Basic and Applied Medical Research. 2014; 4(1): 160-3.

5. Prakash S, Yadav K. Maternal Anemia in Pregnancy: An Overview. IJPPR. 2015; 4(3): 164-79.

6. Defrin. Anemia dalam Kehamilan dan Persalinan. Proceedings of Seminar Nasional Kelainan Medik pada Kehamilan dan Persalinan; 11 April 2015; Jakarta, Indonesia.

7. Departemen Obstetri dan Ginekologi Fakultas Kedokteran Universitas Hasanuddin [Internet]. Anemia dalam Kehamilan. 2018 [cited 3 Maret 2018]. Available from: https://med.unhas.ac.id/obgin/?p=102. 


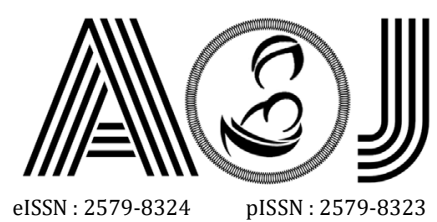

elSSN : 2579-832

Ruang Redaksi Andalas Obstetrics and Gynecology Journal, Lantai 3 PPDS Obstetri dan Ginekologi Universitas Andalas, RSUP DR. M. Djamil Padang, Jl. Perintis Kemerdekaan Padang, Sumatera Barat 25127

8. NHS. Regional Template / Guideline for The Management of Anemia inPregnancy and Postnatally. South West RTC. 2014; 1-5.

9. Sabina A, Iftequer S, Zaheer Z, Khan MM, Khan S. An overview of Anemia in Pregnancy. JIPBS. 2015; 2(2): 144-51

10. Sinco HBC, Penafel COR, Sanchez AS, Jaloma JC, Murillo CM, Figueroa EM, et al. Megaloblastic anemia: Folic acid and vitamin B12 metabolism. Rev Med Hosp Gen Mex. 2015; 78(3): 135-43.

11. Sari L. Anemia dalam Kehamilan [Referat]. Jakarta: Fakultas Kedokteran Ukrida; 2017.

12. Maka SS, Tondare SB, \& Tondare MB. Study of impact of anemia on pregnancy. International Journal of Reproduction, Contraception, Obstetrics and Gynecology. 2016; 6(11): 4847-4850. 